\title{
Ulster Volunteer Force Prisoners of War
}

July 1, 1996

On the 1st of July 1914 many sons of Ulster laid down their lives at the Somme. Veryfew homes throughout the Province were untouched by the slaughter that took place on that fateful morn. In honour of those who died, and those who laid down their lives in the twenty-five year war we have just endured, Ulster Volunteer Force prisoners in Long Kesh were given the following oration.

This gathering today is so very important to us. Today, we remember the tremendous sacrifice made by fellow Ulstermen all those many years ago on a foreign battlefield. That bloody conflagration, that hell on earth was to be the war to end all wars. Alas, we know better. Bravery, duty, and loyalty were the watchwords of these proud and ordinary souls from our country. Their lives were to be ended or never be the same again as they left our streets, the shipyard, the mills, and the fields of home.

Their cause, for King and Country, had also a driving element, that of ensuring the continuance of Northern Ireland (as it was to become) as an integral part of the United Kingdom. The awful price paid by the brave Ulster soldiers is legend. That price will remain with us for ever as we contemplate the stench of rat-infested trenches and the inhuman conditions that governed their lives. How was the smell of rotting flesh and the mixture of gripping fear interspersed with memories of home and loved ones, perhaps never to be seen again.

Our tribute to those brave soldiers is true and honest, and whilst we can only imagine the indescribable suffering they endured, we certainly can, and do understand and identify with their cause. In a different era, we too have fought a war to defy the bully, the political thug who would rail against the democratic wishes of our people. We also know only too well the devious skill of the enemy. We also have chosen to fight rather than to capitulate to the fascist tendencies of Irish Nationalism.

We, the Ulster Volunteer Force, to a man and woman have made conscious decisions to take the fight to the enemy with many, many decisive results. Alas, we have not come through the battle of the past quarter century unscathed. Those comrades lost to us will remain in our hearts for ever. Their sacrifices testify to the preparedness of Ulstermen of whatever generation to stand for freedom and dignity for our people. They, our brave fallen, together with our incarcerated battalion, epitomize the drive and selfless adherence to duty. 
The times have been hard. We still struggle to achieve the return to the bosom of the family and community of those who have given so much for the cause that is Ulster. But, the Brigade Staff of the Ulster Volunteer Force will never rest until every single political prisoner under their authority is free to live a normal and just life, and, against a background of hope, rise to that task with a vigour previously unknown. The desire to create for our people a wholesome society burns within us all. That quest can only ever be completed with the breath of freedom for our Volunteers, all of our Volunteers.

Be assured that no day passes without every endeavour being made to further that aim. Many factors complicate the issue of political prisoner release. Each new day brings hope alternating with frustration. The many-faceted process gripping the attention of our small country is complicated and therefore difficult. We entered that process with complete honour and assure each and every Volunteer of our intention to emerge from this process with that honour intact.

The citizenry of Northern Ireland have suffered more than their fair share of political skullduggery, betrayal, and siege. It is the intent of this organisation to lift the siege, challenge those guilty of skullduggery, those who fear change because of personal interest, and to ensure that no power in our society dare betray the people of this beautiful country. The lust for a true and lasting peace is fierce among the Loyalists of Ulster. Every action of this organisation is in direct response to the desires of the people. That has always been, and will always be, the role of the Ulster Volunteer Force.

This year of 1996 should be a year of destiny. It will also be a time of great fear because there is yet no absolute vision of settlement. All in this community, with its divided traditions, are plotting course in uncharted waters. There exists the need for great vision and exemplary bravery. as we all proceed towards the future. There will be those who will hide behind the mask of fraudulent piety, those great moralists who insist that their own hands are clean but that all others bear the guilt of a whole society. Their failure to deliver our people from pain and tragedy is manifest. They must move! They will move.

The Ulster Volunteer Force will create vision and will continue to act bravely. We will do so because of the sense of duty we feel to the Ulster people. The sacrifices made light the path to the future. The love and affection we all feel for those who cannot be with us on this or any day will ensure that our sense of duty is enhanced. All of our ranks have a role to play in the future of our nation.

For they shall grow not old, as we that are left grow old, Age shall not weary them, nor the years condemn. At the going down of the sun, and in the morning. We shall remember them. 